\title{
Neutralizing Antiidiotypic Antibodies to Factor VIII Inhibitors after Desensitization in Patients with Hemophilia A
}

\author{
Jean Guy Gilles, ${ }^{\star}$ Benoît Desqueper, ${ }^{*}$ Harald Lenk, ${ }^{\ddagger}$ Jozef Vermylen, ${ }^{*}$ and Jean-Marie Saint-Remy* \\ *Center for Molecular and Vascular Biology, Katholieke Universiteit Leuven, 3000 Leuven, Belgium; and ${ }^{\ddagger}$ Universitätes-Kinderklinik, \\ 4317 Leipzig, Germany
}

\begin{abstract}
Hemophilia A patients producing antibodies towards FVIII are usually treated with infusions of high doses of FVIII in an attempt to "desensitize" them. To examine the mechanisms by which such desensitization operates, sequential plasma samples of two unrelated inhibitor patients were analyzed for anti-FVIII and antiidiotypic antibodies before and during infusions of high doses of FVIII. Anti-FVIII antibodies were separated from antiidiotypic antibodies by immunoaffinity chromatography before analysis. We show in the present study that the concentration of anti-FVIII antibodies did not change during a successful desensitization and that antibodies maintained their capacity to inhibit the procoagulant function of FVIII, even though the number of Bethesda units in plasma was reduced to undetectable levels. Using a competition assay with mAbs, we further show that the specificity of human antibodies did not vary significantly during therapy. Finally, we show that the treatment elicited antiidiotypic antibodies, which neutralized the inhibitory capacity of anti-FVIII antibodies. Inhibitor antibodies can therefore not be accurately evaluated in plasma, as their function appears to be neutralized by antiidiotypic antibodies. These findings could have implications for the design of new therapies for hemophilia A patients with inhibitors. (J. Clin. Invest. 1996. 97:1382-1388.) Key words: Factor VIII • inhibitors - desensitization - antiidiotypic antibodies $•$ tolerance
\end{abstract}

\section{Introduction}

More than $20 \%$ of hemophilia A patients under Factor VIII $(\text { FVIII })^{1}$ infusion therapy develop an antibody response toward FVIII $(1,2)$. These antibodies, also called FVIII inhibitors, are routinely detected by the Bethesda method, an assay system carried out in plasma and in which the capacity of anti-

Address correspondence to J.-M. Saint-Remy, M.D. Ph.D., Center for Molecular and Vascular Biology, Katholieke Universiteit Leuven, Herestraat 49, 3000-Leuven, Belgium. Phone: 32-16-345.791; FAX: 32-16-345.990.

Received for publication 25 April 1995 and accepted in revised form 18 December 1995.

1. Abbreviations used in this paper: BU, Bethesda units; FT, flow through; FVIII, Factor VIII; GBS, glycine-buffered saline; NHS-LC, $N$-hydroxysuccinimidyl-LC; OPD, $o$-phenylene-diaminedihydrochloride; rFVIII, recombinant FVIII; RT, room temperature.

J. Clin. Invest.

(C) The American Society for Clinical Investigation, Inc. 0021-9738/96/03/1382/07 \$2.00

Volume 97, Number 6, March 1996, 1382-1388 bodies to neutralize the procoagulant activity of FVIII is measured (3).

Patients presenting with inhibitors are usually treated by regular infusions of high doses of FVIII, a treatment which is successful in $\pm 80 \%$ of patients with low titers of inhibitors $(<10$ Bethesda units $[\mathrm{BU}] / \mathrm{ml}$ ) but only $60 \%$ in patient with high titers $(>10 \mathrm{BU} / \mathrm{ml} ; 4)$. Although the precise mechanism of action of such a "desensitization" therapy is not elucidated, its aim is to reduce antibody titers $<1 \mathrm{BU}$, which is deemed to reflect the suppression of anti-FVIII antibody production.

The detection of anti-FVIII antibodies in plasma is, however, rendered difficult by interference due to other serum proteins, such as antiidiotypic antibodies. The latter are found in the plasma of hemophilia A patients, and it has been suggested by us $(5)$ and others $(6,7)$ that antiidiotypic antibodies could not only inhibit the binding of antibodies to FVIII but also play a role in the down-regulation of anti-FVIII antibody production. We have therefore developed a method by which anti-FVIII antibodies can be separated from possible antiidiotypic antibodies by affinity chromatography (8) and a series of assay systems by which anti-FVIII and antiidiotypic antibodies can be evaluated separately. Our aims were twofold: to determine whether antiidiotypic antibodies could indeed interfere with the evaluation of anti-FVIII antibodies in plasma, and to determine whether infusions of FVIII boosted the production of antiidiotypic antibodies.

We report here the results obtained by analyzing sequential plasma samples of two unrelated patients with inhibitors, before and during a successful desensitization treatment with high doses of FVIII. Our findings show that successful desensitization does not correspond to a reduction in anti-FVIII antibody titers. Instead, such treatment induces the production of specific antiidiotypic antibodies. This is, to our knowledge, the first longitudinal description of the evolution of anti-FVIII and corresponding antiidiotypic antibodies in hemophilia A patients under therapy.

\section{Methods}

Reagents and buffers. Human recombinant FVIII (rFVIII) was obtained from Hyland (Glendale, CA) as material for laboratory use only; this preparation contained vWf but no stabilizer or other protein. $N$-hydroxysuccinimidyl-LC (NHS-LC) biotin was purchased from Pierce (Rockford, IL), and Tween-20 was from Technicon Instruments Corp. (Tarrytown, NY). Buffers used were: glycine-buffered saline (GBS), $270 \mathrm{mM}, \mathrm{pH}$ 9.2; PBS, $8 \mathrm{mM}$, pH 7.4, containing $0.5 \%$ BSA (PBS-BSA) or $0.1 \%$ Tween (PBS-Tween); tris-hydroxyaminomethane, $10 \mathrm{mM}$, pH 7.3, containing $0.5 \%$ casein (Aldrich Chemical Co., Milwaukee, WI) and $0.02 \%$ thimerosal (Sigma Chemical Co., St. Louis, MO), pH 7.2 (Tris-casein).

Patient description and treatment. Patient RS, born in 1984, was diagnosed as severe hemophiliac at the age of $5 \mathrm{mo}$, with a residual FVIII level $<1 \%$. He was treated by infusions of FVIII cryoprecipitate for bleeding episodes. An inhibitor (36 BU) was first detected at 
the age of 3 yr. 14 mo later, the patient underwent a low-dose desensitization trial with 25 U FVIII cryoprecipitate/kg body wt administered three times a week; this resulted in a rise in antibody titer from 2 to $2,640 \mathrm{BU}$ after $4 \mathrm{wk}$ of treatment, followed by a gradual decline to $\pm 10 \mathrm{BU}$. At the age of 6 , a high-dose infusion treatment $(300$ FVIII U/kg body wt per d) was initiated using Profilate SD 1000 (Alpha Therapeutic, Langen, Germany) and followed without interruption. Profilate SD shows a specific activity of 14.2 IU FVIII/mg protein and contains $\pm 200 \mu \mathrm{g} \mathrm{IgG/ml}$. The antibody titer was $8 \mathrm{U}$ before the start of the treatment and peaked at $900 \mathrm{U} 4 \mathrm{wk}$ afterwards. At the end of the fourth month, the level of inhibitor was $<1 \mathrm{BU}$, but it took a year to normalize FVIII recovery. The patient is currently on regular prophylactic treatment with daily infusions of $10 \mathrm{U} \mathrm{FVIII/kg}$ body wt (Profilate SD).

Patient TB was born in 1979 and diagnosed as severe hemophiliac (FVIII $<1 \%$ of normal value) during early infancy. He received infusions of FVIII cryoprecipitate when required for bleeding episodes. An inhibitor was detected at the age of 6 . He was started on a lowdose desensitization treatment at the age of 10, using 25 U FVIII cryoprecipitate $/ \mathrm{kg}$ body wt, administered three times a week. The inhibitor titer increased to $360 \mathrm{U}$ within $4 \mathrm{wk}$ and then gradually declined to levels between 10 and $20 \mathrm{BU}$. At the age of 12, the patient was started on a high-dose continuous daily regimen (300 FVIII U/kg body wt per d) using Profilate SD. The inhibitor titer rose from 18 to 150 BU. 9 mo of therapy were necessary to reduce the level of inhibitors to $<1$ BU. 18 mo later, the FVIII recovery time was normalized. The patient is currently on daily infusions of $30 \mathrm{U} \mathrm{FVIII} / \mathrm{kg}$ body wt using Profilate SD. Both patients were HIV seronegative.

Preparation of human anti-FVIII antibodies. Plasma samples were taken at defined time points during the second desensitization trial: just before the start of FVIII infusions, when inhibitor titer was at its highest, after a significant decrease in titer had been observed, and roughly 1 and 2 yr after the start of infusions. All samples were obtained 12 or $24 \mathrm{~h}$ after the last infusion. Human anti-FVIII antibodies were prepared from serum by salt precipitation, gel filtration chromatography, and adsorption on insolubilized FVIII (8). For the latter, rFVIII was insolubilized on a hydrazide-activated solid phase (Affigel-Hz; Bio-Rad Laboratories, Richmond, CA). Specific antibodies were recovered from the column by sequential elution with acid and alkaline buffers.

The amount of $\mathrm{IgG}$ antibodies recovered by affinity purification and their isotype distribution was measured by specific ELISA as described previously (8). IgG subclasses were determined on plates coated with an anti-mouse IgG1 rat monoclonal IgG (UCL, Brussels, Belgium), followed by a mouse IgG1 specific to either human IgG1 (Oxoid Ltd., Basingstoke, UK), IgG2, or IgG3 (both from Calbiochem Corp., La Jolla, CA). For the determination of IgG4, the corresponding mouse antibody (Calbiochem Corp.) was insolubilized directly on the plate.

Assay for FVIII inhibitors. The titers of inhibitors were determined in plasma using the Bethesda method (3). The capacity of affinity-purified antibodies to neutralize the function of FVIII was evaluated by a chromogenic assay in which thrombin-activated FVIII acts as a cofactor to Factor IXa in the conversion of Factor X to Factor Xa (9), using commercially available kits (Merz \& Dade AG, Düdingen, Switzerland). The assay was carried out as described previously (5). Briefly, $35 \mu \mathrm{l}$ of rFVIII diluted at $150 \mathrm{ng} / \mathrm{ml}$ in $150 \mathrm{mM} \mathrm{NaCl}$ containing $10 \mathrm{mM} \mathrm{CaCl}_{2}$ were mixed with $35 \mu \mathrm{l}$ human anti-FVIII antibodies diluted at a concentration varying from 30 to $2.5 \mu \mathrm{g} / \mathrm{ml}$ in the same buffer. The mixture was incubated for $30 \mathrm{~min}$ at $37^{\circ} \mathrm{C}$. $50 \mu \mathrm{l}$ was then added to a vial containing the chromogenic assay reagents. Control experiments included rFVIII incubated without specific antibodies or with the same concentration of autologous antibodies from which anti-FVIII antibodies had been removed by adsorption (flow-through fractions [FT]).

Assay for anti- $v W f$ antibodies. Microtitration plates were incubated for $2 \mathrm{~h}$ at room temperature (RT) with $50 \mu \mathrm{l}$ rabbit $\mathrm{F}\left(\mathrm{ab}^{\prime}\right)_{2}$ fragments specific for human vWf. These antibodies were obtained from Dakopatts (Copenhagen, Denmark) and digested with pepsin by standard procedures. The plates were then washed three times with PBS-Tween before addition of $50 \mu$ l of a solution of purified human vWf (obtained by courtesy of Dr. Mirella Ezban, Novo Nordisk, Copenhagen, Denmark), which was diluted to $2 \mathrm{U} / \mathrm{ml}$ in casein buffer. The plates were incubated for $2 \mathrm{~h}$ at RT and then washed four times with PBS-Tween containing $0.4 \mathrm{M} \mathrm{CaCl}_{2}$ to eliminate possible residual FVIII contamination. $50 \mu \mathrm{l}$ of a human $\mathrm{IgG}$ sample $(1 \mathrm{mg} / \mathrm{ml}$ for IgG preparations before adsorption or $10 \mu \mathrm{g} / \mathrm{ml}$ for affinity-purified anti-FVIII antibodies) diluted in casein buffer were then added for an incubation of $2 \mathrm{~h}$ at RT. The plates were washed three times with PBS-Tween, and the detection of bound $\mathrm{IgG}$ was carried out by sequential addition of $50 \mu \mathrm{l}$ peroxidase-conjugated goat IgG specific for human IgG (diluted 1/1,000 in casein buffer) and $100 \mu \mathrm{l} o$-phenylene-diaminedihydrochloride (OPD). Control experiments included a panel of mouse mAb to FVIII and an mAb to vWf (obtained by courtesy of Dr. J. Arnout).

Protein biotinylation. A 1- $\mathrm{ml}$ solution of $360 \mu \mathrm{g} / \mathrm{ml}$ of $\mathrm{rFVIII}$ was prepared in $150 \mathrm{mM} \mathrm{NaCl}$ containing $10 \mathrm{mM} \mathrm{CaCl}_{2}$ and labeled with biotin by addition of $100 \mu \mathrm{l}$ of a $10 \mathrm{mg} / \mathrm{ml}$ stock solution of NHSLC-biotin (8). After an incubation of $2 \mathrm{~h}$ at $4^{\circ} \mathrm{C}$ the mixture was dialyzed against the same buffer. Affinity-purified human IgG were labeled with biotin by the same method except for the use of $500 \mu \mathrm{g}$ protein/ml and of a $150 \mathrm{mM} \mathrm{NaCl}$ solution without $\mathrm{CaCl}_{2}$.

Production and characterization of anti-FVIII mouse mAbs. $\mathrm{mAbs}$ were produced in BALB/c mice as described previously (8). Hybridomas secreting anti-FVIII antibodies were identified by direct binding to insolubilized rFVIII. Positive hybridomas were cloned by limiting dilution and expanded. Antibody isotypes were determined by specific immunoassays. mAb specificity was evaluated on nitrocellulose blots containing native or thrombin-digested FVIII as described (8; Gilles, J.G.G., K. Peerlinck, J. Arnout, J. Vermylen, and J.-M.R. Saint-Remy, manuscript submitted for publication). The capacity of mAbs to neutralize the function of FVIII was evaluated with the Bethesda method and in the chromogenic assay described above.

Epitope mapping. The FVIII regions recognized by affinity-purified human antibodies were identified in an assay system in which affinity-purified human antibodies compete with mAbs for the binding to insolubilized FVIII (8). For this, polystyrene microtitration plates (Nunc, Roskilde, Denmark) were incubated for $2 \mathrm{~h}$ at RT with a solution of $2 \mu \mathrm{g} / \mathrm{ml} \mathrm{rFVIII} \mathrm{in} \mathrm{GBS} \mathrm{and} \mathrm{then} \mathrm{washed} \mathrm{with} \mathrm{PBS-Tween.} 50$ $\mu l$ of an anti-FVIII mAb diluted at $0.5 \mu \mathrm{g} / \mathrm{ml}$ in PBS-BSA was mixed with $50 \mu \mathrm{l}$ of a sample containing human anti-FVIII antibodies diluted at a concentration varying from 30 to $2.5 \mu \mathrm{g} / \mathrm{ml}$ in the same buffer. $50 \mu \mathrm{l}$ of the mixture was added to FVIII-coated plates for a 2-h incubation at RT. The plates were washed four times with PBSTween before addition of $50 \mu \mathrm{l}$ biotin-conjugated goat IgG specific to mouse Fc $\gamma$ (Tago Inc., Burlingame, CA), which was diluted 1/4,000 in Tris-casein. The plates were incubated for a further $2 \mathrm{~h}$ at RT and then washed four times. $50 \mu \mathrm{l}$ avidin-peroxidase (Sigma Chemical Co.) diluted at $1 \mu \mathrm{g} / \mathrm{ml}$ in PBS-BSA was then added. After $30 \mathrm{~min}$ at $\mathrm{RT}, 50 \mu \mathrm{l}$ OPD was added and the absorbance read at $492 \mathrm{~nm}$.

Assays for antiidiotypic antibodies. The detection of antiidiotypic antibodies was carried out using IgG FT fractions. Antiidiotypic antibodies were detected by their capacity to recognize the variable part of anti-FVIII mAbs and to inhibit the binding of labeled FVIII to mAbs $(5,8)$.

For the binding assay, polystyrene microtitration plates (Nunc) were incubated overnight with $50 \mu \mathrm{l}$ of a given mAb diluted at $2 \mu \mathrm{g} /$ $\mathrm{ml}$ in GBS. The plates were then washed before addition of $50 \mu \mathrm{l}$ of an FT sample containing $500 \mu \mathrm{g} \mathrm{IgG/ml} \mathrm{in} \mathrm{PBS-BSA.} \mathrm{After} \mathrm{an} \mathrm{incu-}$ bation of $2 \mathrm{~h}$ at RT, the plates were washed again. The binding of human antibodies was then detected by sequential addition of peroxidase-labeled goat IgG specific for human Fcy (Sigma Chemical Co.) and OPD. Control experiments included plates coated with an $\mathrm{mAb}$ of the same isotype but of unrelated specificity, and substitution of FT samples by a multidonor pool of $\gamma$-globulins.

For the inhibition assay, $50 \mu \mathrm{l}$ of biotin-labeled rFVIII diluted at 


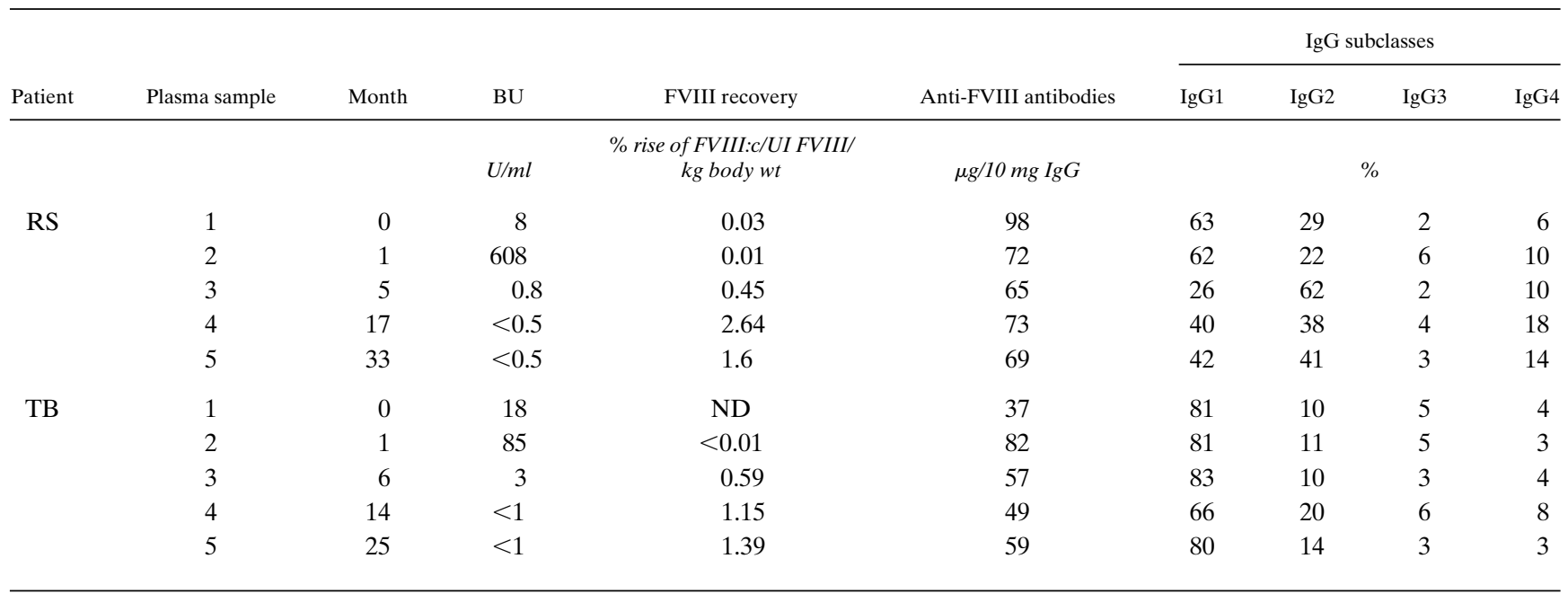

Evolution of the level of anti-FVIII antibodies during desensitization with high doses of FVIII. The number of BU was evaluated on plasma, The total amount of anti-FVIII antibodies and their isotypic distribution were measured after affinity purification on FVIII-Affigel.

$10 \mu \mathrm{g} / \mathrm{ml}$ in Tris-casein was mixed with $50 \mu \mathrm{l}$ of an FT sample containing antiidiotypic antibodies, previously diluted at either 250 or 500 $\mu \mathrm{g} / \mathrm{ml}$ in PBS-BSA. A $50-\mu l$ aliquot of the mixture was added to the $\mathrm{mAb}$-coated plates for an incubation of $2 \mathrm{~h}$ at RT. After washing, avidin-peroxidase and OPD were added as described above. Control experiments included addition of biotin-labeled FVIII mixed with a pool of human $\gamma$-globulins.

Reconstitution experiments. $50 \mu \mathrm{l}$ of a solution containing $2 \mu \mathrm{g} / \mathrm{ml}$ of biotin-labeled affinity-purified anti-FVIII antibodies in Tris-casein were mixed with $50 \mu \mathrm{l}$ of an FT sample diluted at $500 \mu \mathrm{g} / \mathrm{ml}$ in the same buffer. The mixture was incubated for $2 \mathrm{~h}$ at RT before addition to polystyrene plates preincubated with $2 \mu \mathrm{g} / \mathrm{ml} \mathrm{rFVIII} \mathrm{in} \mathrm{GBS.} \mathrm{After}$ an incubation of $2 \mathrm{~h}$ at RT, the plates were washed and the binding of anti-FVIII antibodies was evaluated by addition of avidin-peroxidase and OPD as described above. Control experiments include the use of pooled human $\gamma$-globulins as a substitute for FT samples.

\section{Results}

Two hemophilia A patients who had developed an anti-FVIII antibody response were treated by infusions of high doses of FVIII in an attempt to desensitize them, i.e., to reduce specific antibodies to undetectable levels as assessed by a functional coagulation assay (Bethesda method). Five plasma samples for each patient were available for analysis, one before the start of desensitization and four while in therapy, including two samples taken when inhibitors were no longer detected in plasma.
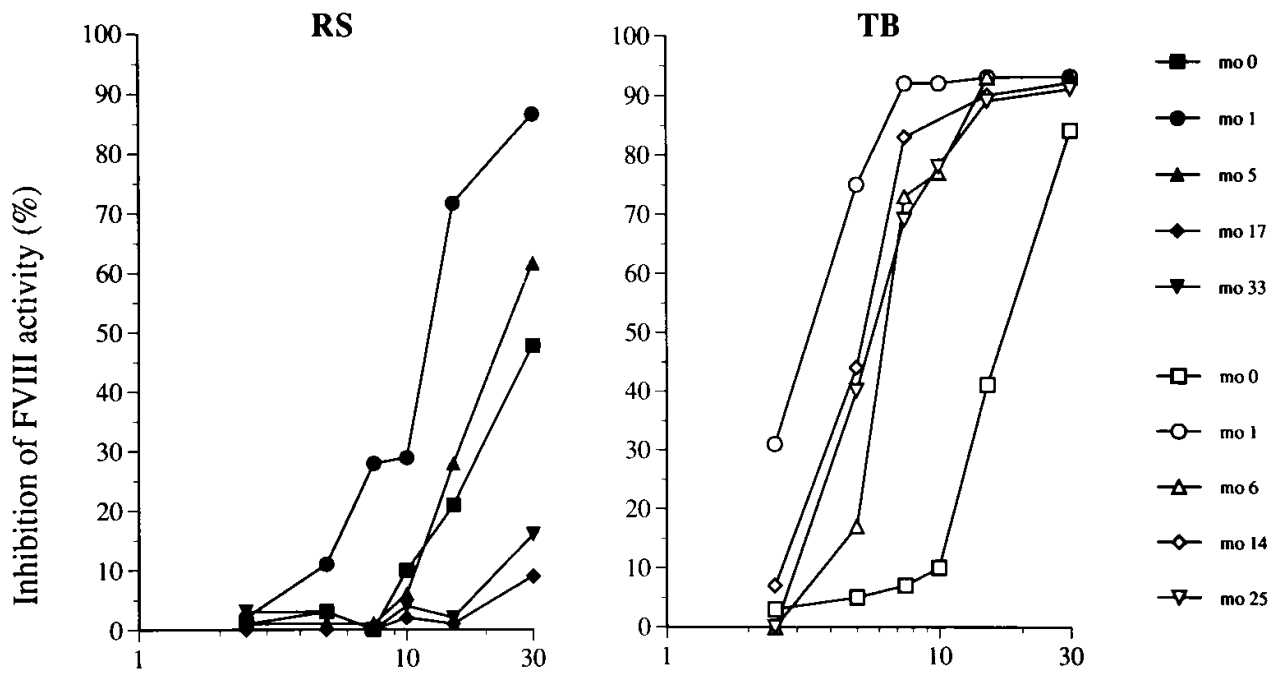

Affinity-purified human anti-FVIII antibodies $(\mu \mathrm{g} / \mathrm{ml})$
Figure 1. Inhibition of FVIII function by human anti-FVIII antibodies. Evaluation of the inhibitory capacity of affinity-purified human anti-FVIII antibodies prepared from plasma samples taken at different time points during the desensitization treatment. A $35-\mu l$ aliquot of $\mathrm{rFVIII}$ at $150 \mathrm{ng} / \mathrm{ml}$ was mixed for $30 \mathrm{~min}$ at $37^{\circ} \mathrm{C}$ with an equal volume of antibodies diluted at varying concentrations. Inhibition was measured in a chromogenic assay in which FVIII acts as a cofactor to FIXa in the proteolytic activation of FX. The last two points in time illustrate the inhibitory capacity of antibodies when inhibitors were no longer detected in plasma. Control experiments included the incubation of rFVIII without antibodies or with autologous FT fractions used at the same concentration. 
The follow-up period covered 33 and 25 mo for patients RS and $\mathrm{TB}$, respectively. The same plasma samples were used for assays described in Table I and in all of the figures.

Evolution of total anti-FVIII antibodies during desensitization. Antibodies to FVIII were purified by affinity chromatography from each plasma sample. The amounts of total antiFVIII antibodies recovered from the immunosorbent together with results of the Bethesda method, which was carried out on plasma, are shown in Table I. It can be seen that there was either no (patient RS) or only marginal increase (patient TB) in the amount of antibodies $4 \mathrm{wk}$ after the start of the desensitization treatment, suggesting that the increase in BU did not reflect a mere increase in antibody production. Moreover, although the number of $\mathrm{BU}$ gradually declined over time to undetectable values, the yield of antibodies remained practically unchanged over the entire follow-up time period. The isotypic distribution of anti-FVIII antibodies showed a relative increase in IgG2 and IgG4 for patient RS, but no significant changes for patient TB. As the rFVIII used for adsorption contained vWf, we checked the eluates for the presence of antivWf antibodies, which could interfere in the assay systems used here. No such antibodies were found using a direct binding ELISA with a sensitivity of $10 \mathrm{ng} / \mathrm{ml}$ (data not shown).

Specificity of anti-FVIII antibodies. The discrepancy between the results of the Bethesda method and those of total anti-FVIII antibodies prompted us to verify whether affinitypurified anti-FVIII antibodies maintained their capacity to neutralize FVIII during the follow-up period and to examine whether antibodies with novel specificity, but without inhibitory capacity, had been produced as a result of the treatment.

The capacity to neutralize the function of FVIII was evaluated in a chromogenic assay in which FVIII acts as a cofactor to FIX in the activation of FX. The results are shown in Fig. 1. It can be seen that there is in both cases an increase in the proportion of inhibitory antibodies, or of their affinity, which is, however, not proportional to the increase in BU (second plasma samples). Moreover, plasma samples taken at the time when inhibitors were undetectable by the Bethesda method still contained inhibitory antibodies. The concentration of the latter did not change significantly with time for patient TB; for patient RS, a two- to threefold reduction was observed compared with initial levels, which was much less than that expected from the Bethesda results.

Next, to determine whether the specificity of antibodies had changed with time, we used an assay system in which human antibodies competed with mAbs for the binding to insolubilized FVIII. 10 mAbs were used for this analysis; no significant competition was observed for $2 \mathrm{mAbs}$ (mAbs 7 and 18). Results for the other $8 \mathrm{mAbs}$ are given in Fig. 2, which shows that, for the two patients, the profile of antibody specificity did not change with time. Instead, in a few instances (see mAbs 1 and 12), the capacity of human antibodies to inhibit the binding of mAbs increased, suggesting that the treatment increased either the proportion or the affinity of antibodies toward these sites. Of particular interest are the results obtained with $\mathrm{mAb}$ 15 , an anti-heavy chain antibody that completely inhibited the procoagulant activity of FVIII: here again, the level of human antibodies did not change significantly with treatment, in contrast with the evolution of functional inhibitors assessed by the Bethesda method in plasma. Remarkably, mAb 2 seems to identify an epitope that is precisely recognized by human antibodies of both patients; this epitope is located in the A2 do- main in between residues 606 and 740 (as determined by courtesy of Dr. Dorothea Scandella, Holland Laboratory, American Red Cross, Rockville, MD).

Evolution of antiidiotypic antibodies. As neither the concentration of anti-FVIII antibodies nor their specificity had changed with the desensitization treatment, we evaluated whether antibodies had been induced toward the idiotypes carried by anti-FVIII antibodies. For this, we used the IgG fractions that were not retained on the FVIII immunosorbent (flow-through, FT). These fractions did not contain residual anti-FVIII antibodies or FVIII that would have leached from the immunosorbent (data not shown). Two assay systems were used to detect antiidiotypic antibodies: a binding assay in which FT Igs reacted with the variable part of specific mAbs and an inhibition assay in which FT Igs inhibited the binding of labeled FVIII to mAbs.

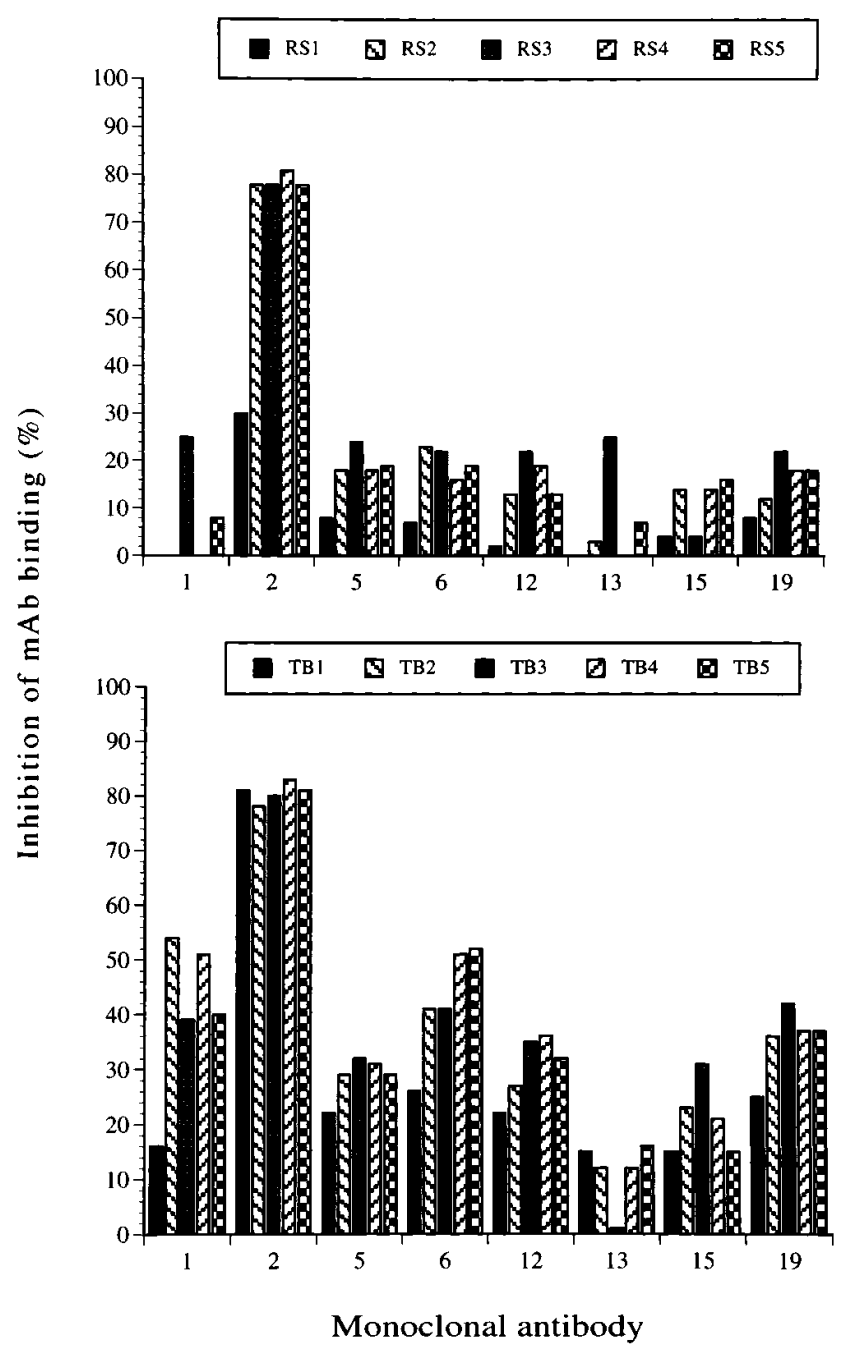

Figure 2. Epitope mapping of human anti-FVIII antibodies. FVIII regions recognized by human antibodies were identified using an assay system in which affinity-purified human antibodies inhibited the binding of mAbs to FVIII-coated plates. $50 \mu \mathrm{l}$ of a $0.5-\mu \mathrm{g} / \mathrm{ml} \mathrm{mAb}$ solution made in PBS-BSA was mixed for $2 \mathrm{~h}$ at RT with $50 \mu \mathrm{l}$ of a dilution of human anti-FVIII antibodies. A $50-\mu l$ aliquot of the mixture was then added to the FVIII-coated plates. The figure illustrates the maximum inhibition obtained using $30 \mu \mathrm{g} / \mathrm{ml}$ human antibodies.

Plasma samples were obtained before (1) and at different times (2 to 5) during desensitization by FVIII infusions. 


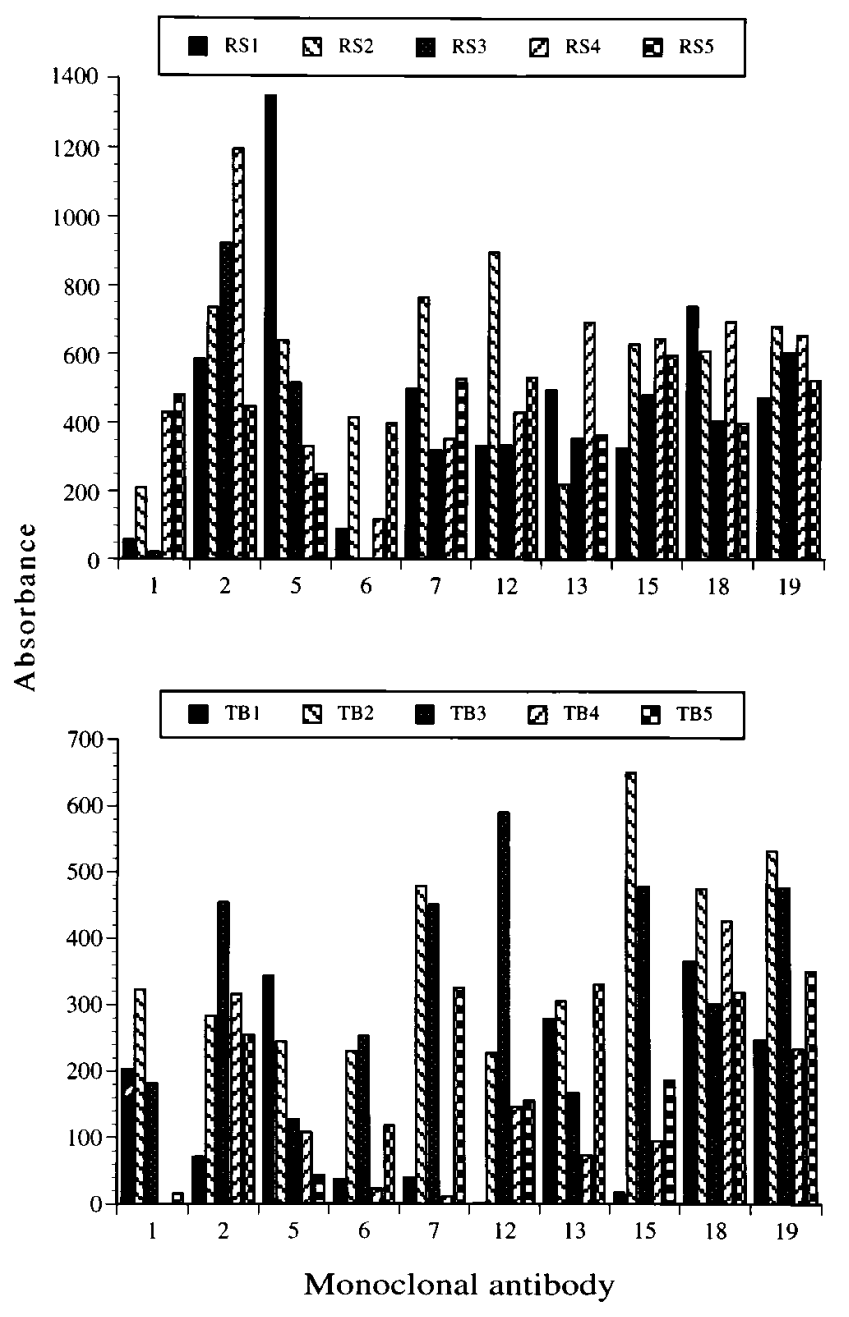

Figure 3. Binding of human antibodies to the variable part of antiFVIII mAbs. The presence of antiidiotypic antibodies in human FT fractions was assessed by measuring their capacity to bind directly to the variable regions of anti-FVIII mAbs. Plates were incubated overnight with a given $\mathrm{mAb}$. After washing, FT fractions containing 500 $\mu \mathrm{g} \mathrm{IgG/ml}$ were added for $2 \mathrm{~h}$ at RT. The binding of human IgG was detected by addition of specific goat IgG. FT samples taken before (1) and at different time intervals (2 to 5) during the desensitization treatment were analyzed. Control experiments showed essentially no binding of FT fractions to mAbs of unrelated specificity and no binding of pooled $\gamma$-globulins to anti-FVIII mAbs (not shown).

As can be seen from Fig. 3, antibodies that bound to antiFVIII mAbs became detectable, or their level increased, when infusions of high doses of FVIII were started. This is well illustrated, for instance, for antibodies binding to $\mathrm{mAb} 2$, which defines precisely an epitope recognized by human antibodies. One notable exception, however, concerns mAb 5, a heavy chain-specific $\mathrm{mAb}$ that showed partial competition with $\mathrm{mAb} 2$. Control experiments using $\mathrm{mAbs}$ of unrelated specificity did not show any significant binding of FT Ig fractions (data not shown).

We then determined whether some of these antiidiotypic antibodies could inhibit the binding of labeled FVIII to insolubilized mAbs. Fig. 4 shows that it was in no cases possible to detect such antibodies in the FT fractions taken before treatment. However, these antibodies were often found as soon as

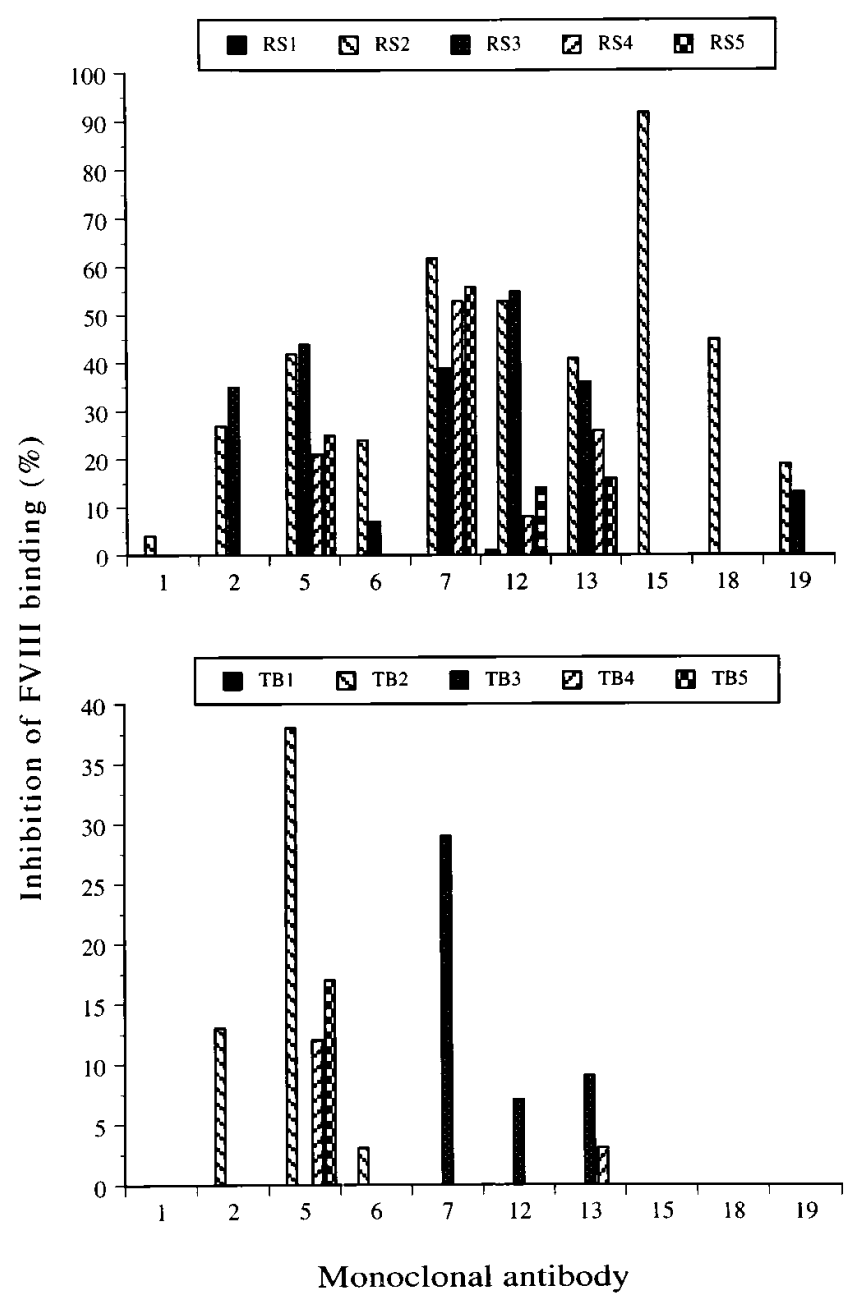

Figure 4. Inhibition of the binding of FVIII to mAbs by human antibodies. Human antiidiotypic antibodies were detected by their capacity to inhibit the binding of labeled rFVIII to plates coated with specific $\mathrm{mAbs}$. For this, an aliquot of biotin-labeled rFVIII was mixed with an equal volume of an FT sample adjusted at $500 \mu \mathrm{g} / \mathrm{ml}$ in PBSBSA. The mixture was added to $\mathrm{mAb}$-coated plates, and the binding of labeled rFVIII was measured by sequential addition of avidin-peroxidase and OPD. Samples taken before the start of the desensitization were compared with those obtained at different time intervals during the treatment. Substitution of human antibodies by a multidonor pool of $\gamma$-globulins had no effect on FVIII binding (not shown).

the treatment started. In some cases (see patient RS mAb 15), an almost complete inhibition of FVIII binding was observed.

Reconstitution experiments. The capacity of antiidiotypic antibodies to inhibit the binding of affinity-purified human antibodies to FVIII was measured in a reconstitution experiment. FT samples taken before and during therapy were compared, using anti-FVIII antibodies obtained before treatment. As shown in Fig. 5, an FT fraction prepared from a plasma sample taken when the number of BU had already significantly decreased (sample 3 ) inhibited the binding of anti-FVIII antibodies to FVIII-coated plates to a significantly higher extent than the pretreatment FT fraction. Because substitution of FT fractions by pooled $\gamma$-globulins resulted in no inhibitory effect, this finding was taken as evidence for the induction of antiidiotypic antibodies to human anti-FVIII antibodies. 


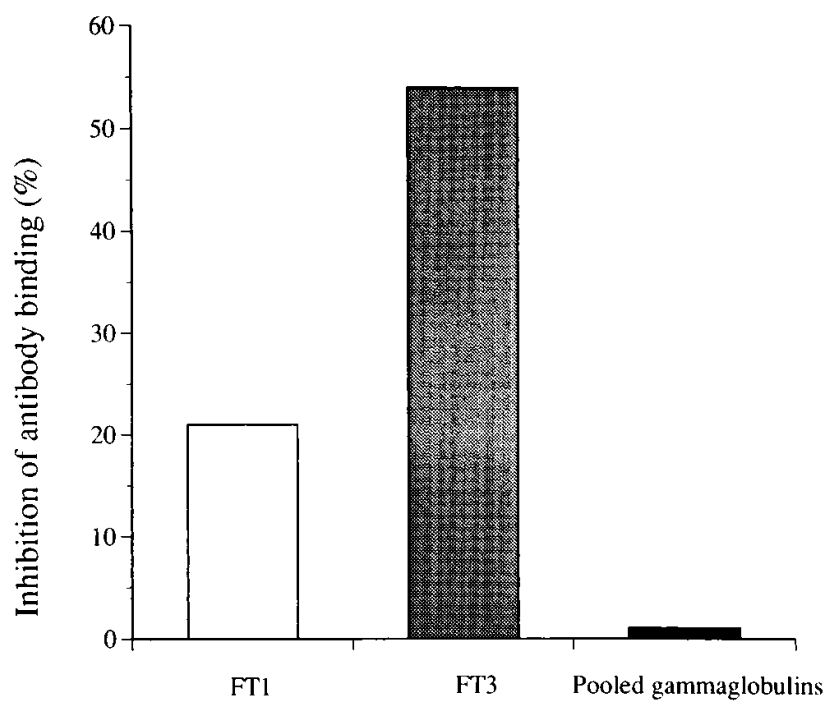

Figure 5. Inhibition of human antibodies to FVIII by human antiidiotypic antibodies. The capacity of antiidiotypic antibodies to inhibit the binding of human antibodies to rFVIII was studied in an assay in which affinity-purified human antibodies were mixed with FT fractions before addition to FVIII-coated plates. For this, $2 \mu \mathrm{g} / \mathrm{ml}$ of biotin-labeled affinity-purified anti-FVIII antibodies in Tris-casein were mixed for $2 \mathrm{~h}$ at RT with $50 \mu \mathrm{l}$ of an FT sample diluted at 500 $\mu \mathrm{g} / \mathrm{ml}$ in the same buffer. FT fractions taken before (FT1) and 5 mo after the start of desensitization (FT3) were used and added to antiFVIII antibodies obtained in the predesensitization period. Control experiments included the substitution of FT fractions by pooled $\gamma$-globulins.

\section{Discussion}

Hemophilia A patients presenting with antibodies towards FVIII are usually treated with regular infusions of FVIII at doses that vary from one investigator to the other (10-13). The success or failure of such a treatment is decided based upon the capacity of the patient's plasma to neutralize the procoagulant activity of FVIII, with a reduction $<1$ BU considered as the objective to achieve. Through the analysis of sequential plasma samples obtained from two unrelated patients, we show that desensitization may in fact not reduce the level of anti-FVIII antibodies, that antibodies maintain their capacity to neutralize the procoagulant activity of FVIII, and that no significant changes occur with regard to antibody specificity.

The amount of anti-FVIII antibodies was evaluated after adsorption on insolubilized FVIII, a method that had been previously standardized (5). Whenever necessary, IgG samples were passed several times on the FVIII immunosorbent until no specific antibodies could be detected in the FT fractions. The isotypic profile of eluted antibodies showed a normal distribution, except for a slightly raised proportion of $\mathrm{IgG} 2$ in one of the two patients, a finding that is usual with the adsorption method used here and that is possibly related to the recognition of carbohydrate moieties on FVIII, as already discussed (8). Functional inhibitors were recovered in the eluates at each time point during the study, even when they were not detected in the plasma. It can therefore be concluded that reduction of BU titers $<1 \mathrm{U}$ does not mean that functional inhibitors have been eliminated. It suggests, rather, that an interference, likely to be antiidiotypic in nature, existed in plasma.
That no change in antibody specificity occurred during treatment with FVIII was concluded from an assay system in which a panel of $10 \mathrm{mAbs}$ was used. These mAbs were selected out of a large series of anti-FVIII antibodies and are probably representative of the antibody repertoire that BALB/c mice can mount toward human FVIII. Although it can be deduced from the limited capacity of human antibodies to inhibit the binding of mAbs to FVIII (see Fig. 2) that mAbs do not recognize epitopes identical to those bound by human antibodies, we think mAbs can at least identify the main regions to which human antibodies bind. The difference in antibody specificity should nevertheless be kept in mind when trying to identify FVIII epitopes relevant to patients' immune response. One possible exception concerns mAb 2, which defines an FVIII epitope that is clearly close, if not identical, to an epitope recognized by human antibodies. Interestingly, both patients have antibodies toward this epitope, which, however, was not prominent in the immune response made by other hemophiliac patients analyzed so far (8). The question of whether the formation of antibodies toward the region of FVIII defined by $\mathrm{mAb} 2$ is related to the use of FVIII cryoprecipitates is currently under investigation.

Anti-FVIII mAbs were also used to detect antiidiotypic antibodies, and it is shown here that the treatment increased human antibody binding to $\mathrm{mAb} \mathrm{V}$ regions. As the patients had not received an FVIII preparation that could be contaminated by $\mathrm{mAbs}$, and as the binding was specific for anti-FVIII mAbs, we think it corresponds to an idiotype-antiidiotype interaction. In addition, at least some of the human antiidiotypic antibodies recognized the antigen-binding site of mAbs, as shown by their capacity to displace FVIII from its binding to mAbs. However, this was observed mainly during the early months of treatment with FVIII, indicating that antiidiotypic specificity varied with time, whereas the total level of antiidiotypic antibodies was not reduced (Fig. 3). One might argue that antiidiotypic antibodies were passively given with the FVIII preparation used to desensitize patients. It can indeed be calculated that patients received $\pm 30 \mathrm{mg} \mathrm{IgG/d}$, a significant amount but one unlikely to contain a higher proportion of antiidiotypic antibodies than that found in healthy blood donors (5), which therefore renders it unlikely to be of physiological relevance or to interfere in our assay systems.

In an attempt to circumvent the difficulties inherent in the use of antibodies of different origins, a reconstitution experiment was carried out in which the binding of affinity-purified human antibodies to FVIII was prevented by preincubation with FT fractions taken before and during desensitization with FVIII. Although such experiments are difficult to carry out because of the polyclonal nature of both the anti-FVIII and antiidiotypic immune responses, we think the results suggest an explanation why inhibitors were no longer detected in the plasma of patients under desensitization. Further insight in this matter would be gained if human mAbs were available; methods to produce them are currently under development in our laboratory.

Our findings indicate that induction of unresponsiveness to FVIII by high-dose FVIII infusions does not involve losing the capacity to produce anti-FVIII antibodies. Instead, an inhibition is exerted at the effector level, most likely because of the presence of antiidiotypic antibodies. A key question, which remains unanswered for now, is whether antiidiotypic antibodies can actively down-regulate the production of anti-FVIII anti- 
bodies. This has been suggested from the observation that an inverse relationship exists between the level of anti-FVIII antibodies and that of corresponding antiidiotypic antibodies in patients with acquired inhibitors (14), and it is certainly supported by animal experiments (15). If this happens to be the case in the human immune response to FVIII, then therapeutic strategies by which antiidiotypic antibody production is boosted would be worth designing. One of the main advantages of such treatments would be their high specificity and potential low cost compared with current treatments for FVIII inhibitors.

In conclusion, and with the limitations related to the analysis of only two patients, we think that the present results challenge the current view of the mechanism by which desensitization is effective for patients with FVIII inhibitors, and they might provide clues for novel therapies for such patients. One possible approach has already been reported by us (Gilles, J.G.G., J. Arnout, K. Peerlinck, J. Vermylen, and J.M.R. SaintRemy, manuscript in preparation), in which patients were treated by injections of immune complexes made of FVIII and autologous specific antibodies, which resulted in a significant reduction in the level of FVIII inhibitors.

\section{Acknowledgments}

The authors thank Kathleen Peerlinck for reviewing the manuscript, Yves Delmarcelle for expert technical assistance, and Brigitte Firket for editorial help.

\section{References}

1. Schwarzinger, I., I. Pabinger, C. Korninger, F. Hasckeke, M. Kundi, H. Niessner, and K. Lechner. 1987. Incidence of inhibitors in patients with severe and moderate hemophilia A treated with factor VIII concentrates. Am. J. Hematol. 24:241-245.

2. McMillan, C.W., S.S. Shapiro, D. Whitehurst, L.W. Hoyer, A. Vijaya Rao, J. Layerson, and the hemophilia study group. 1988. The natural history of factor VIII: c inhibitors in patients with hemophilia A: a national cooperative study. II. Observations on the initial development of factor VIII: c inhibitors. Blood. 71:344-348.

3. Kasper, C.K., L.M. Aledort, R.B. Counts, J.R. Edson, J. Fratantone, D. Green, J.W. Hempton, M.N. Hilgartner, J. Lazarson, P.H. Levin, et al. 1975. A more uniform measurement of factor VIII inhibitors. Thromb. Res. 34:869-872.

4. Mariani, G., A. Ghirardini, and R. Bellocco. 1994. Immune tolerance in hemophilia: principal results from the international registry. Thromb. Haemostasis. 72:155-158.

5. Gilles, J.G., and J.M.R. Saint-Remy. 1994. Healthy subjects produce both anti-factor VIII and specific antiidiotypic antibodies. J. Clin. Invest. 94:14961505.

6. Rossi, F., Y. Sultan, and M.D. Kazatchkine. 1988. Anti-idiotypes against autoantibodies and alloantibodies to VIII:C (anti-haemophilic factor) are present in therapeutic polyspecific normal immunoglobulins. Clin. Exp. Immunol. 74:311-316.

7. Sultan, Y., M.D. Kazatchkine, P. Maisonneuve, and U.F. Nydegger. 1984. Anti-idiotypic suppression of auto-antibodies to factor VIII (anti-hemophilic factor) by high dose intravenous gammaglobulin. Lancet. ii:765-768.

8. Gilles, J.G.G., J. Arnout, J. Vermylen, and J.M.R. Saint-Remy. 1993. Anti-factor VIII antibodies of hemophiliac patients are frequently directed towards nonfunctional determinants and do not exhibit isotypic restriction. Blood. 82:2452-2461.

9. Svendsen, L., M. Brogli, G. Lindeberg, and K. Stocker. 1984. Differentiation of thrombin- and factor Xa-related amidiolytic activity in plasma by means of synthetic thrombin inhibitor. Thromb. Res. 34:457-464.

10. Brackmann, H., F. Etzel, P. Hoffmann, and H. Egli. 1977. The successful treatment of acquired inhibitors against factor VIII. Thromb. Haemostasis. 38: 369-374.

11. Gomperts, E.D., J. Stanley, J.A. Church, R. Sakai, and J. Lemire. 1984. Induction of tolerance to FVIII in a child with a high-titer inhibitor: in vitro and in vivo observations. J. Pediatr. 104:70-75.

12. Van Leeuwen, E., E. Mauser-Bunschoten, P. Van Dijken, A. Kok, E. Sjamsoendin-Visser, and J. Sixma. 1986. Disappearance of factor VIII: C antibodies in patients with haemophilia A upon frequent administration of FVIII in intermediate or low dose. Br. J. Haematol. 64:291-297.

13. Mauser-Bunshoten, R., J. Nilsson, and C. Kasper. 1991. Immune tolerance, a 1990 approach. In Hemophilia and von Willebrand's Disease in the 1990s. J.M. Lusher and C.M. Kessler, editors. Elsevier Science, New York. 265 271.

14. Sultan, Y., F. Rossi, and M.D. Kazatchkine. 1987. Recovery from antiVIIIc (anti-hemophilic factor) autoimmune disease is dependent on generation of anti-idiotypes against anti-VIIIc autoantibodies. Proc. Natl. Acad. Sci. USA. 84:828-831.

15. Kluskens, L., and H. Köhler. 1974. Regulation of immune response by autogenous antibody against receptor. Proc. Natl. Acad. Sci. USA. 71:5083-5087. 